\title{
Life cycle and morphometry of Rugose spiraling whitefly, Aleyrodicus rugioperculatus Martin (Hemiptera: Aleyrodidae) on coconut
}

\author{
Saranya M. \\ Department of Agricultural Entomology, Tamil Nadu Agricultural University, Coimbatore \\ -641003 (Tamil Nadu), India \\ Kennedy J.S.* \\ Department of Agricultural Entomology, Tamil Nadu Agricultural University, Coimbatore \\ -641003 (Tamil Nadu), India \\ Jeyarani S. \\ Department of Agricultural Entomology, Tamil Nadu Agricultural University, Coimbatore \\ -641003 (Tamil Nadu), India \\ Anandham R. \\ Department of Agricultural Microbiology, Tamil Nadu Agricultural University, Coimbatore \\ -641003 (Tamil Nadu), India \\ Bharathi N. \\ Department of Plant Molecular Biology and Bioinformatics, Tamil Nadu Agricultural University, \\ Coimbatore-641003 (Tamil Nadu), India \\ *Corresponding author. Email: jskennedy@tnau.ac.in
}

\section{Article Info}

https://doi.org/10.31018/ jans.v13iSI.2807

Received: March 22, 2021

Revised: May 14, 2021

Accepted: June 3, 2021

\section{How to Cite}

Saranya M. et al. (2021). Life cycle and morphometry of Rugose spiraling whitefly, Aleyrodicus rugioperculatus Martin (Hemiptera: Aleyrodidae) on coconut. Journal of Applied and Natural Science, 13 (SI), 100 - 104. https://doi.org/10.31018/jans.v13iSI.2807

\begin{abstract}
The present study investigated the biology and morphometric analysis of rugose spiralling whitefly (RSW), Aleyrodicus rugioperculatus on coconut under mini net house condition at Department of Agricultural Entomology, Tamil Nadu Agricultural University -Coimbatore during 2019-2020. The biology of rugose spiralling whitefly was studied by clip cage method and morphometrics were done using Leica image analyser. Total lifecycle of rugose spiraling whitefly was $56.23 \pm 2.20$ days. Developmental period of egg, nymphal, pupal and adult period was $8.47 \pm 0.26,17.46 \pm 0.76,10.30 \pm 0.29$ and $20.00 \pm 1.00$ days, respectively. In morphometrics, Length and width of egg $(0.31 \pm 0.01 \mathrm{~mm}$ and $0.11 \pm 0.02 \mathrm{~mm})$, nymphal $(0.94 \pm 0.01 \mathrm{~mm}$ and $0.82 \pm 0.01$ $\mathrm{mm})$, pupal $(1.23 \pm 0.01 \mathrm{~mm}$ and $1.00 \pm 0.01 \mathrm{~mm})$ was recorded. A nymphal parasitoid, Encarsia guadeloupae can be potential natural enemy for effective management of rugose spiraling whitefly.
\end{abstract}

Keywords: Biology, Coconut, Encarsia guadeloupae, Morphometrics, Rugose spiraling whitefly

\section{INTRODUCTION}

Rugose Spiraling Whitefly (RSW), Aleurodicus rugioperculatus Martin (Hemiptera: Aleyrodidae) was first described as a pest of coconut in Belize and Mexico during 2004 (Martin, 2004) and In 2009, RSW was recorded as a pest of gumbo limbo (Bursera simaruba L) in Miami-Dade County (South Florida, USA) (Stocks and Hodges 2012). In India, it was first observed in the coconut farms of the Pollachi area of Tamil Nadu and Palakkad area of Kerala during July-August 2016. Percent infestation of RSW, $25-40 \%$ and $40-60 \%$ were recorded in banana and coconut leaves, respectively
(Selvaraj et al., 2017).

RSW has a broad range of host plants (96), including ornamentals, palms, weeds, and native and invasive plant species (Stocks and Hodges, 2012). In Florida, $22 \%$ of palm species, $16 \%$ of gumbo limbo, $10 \%$ of Calophyllum spp., $9 \%$ of avocado, $4 \%$ of black olive, and $3 \%$ of mango varieties were infested by RSW during 2009- 2012 (Francis et al., 2016). In India, incidence and damage of RSW was recorded on 12 plant species viz., coconut (Cocos nucifera), banana (Musa spp.), sapota (Manilkara zapota), guava (Psidium guajava), mango (Mangifera indica), Indian almond (Terminalia catappa), water apple (Syzygium 
samarangense), ball tree (Calophyllum inophyllum), betel vine (Piper betle), rubber fig (Ficus elastica), butterfly palm (Dypsis lutescens) and ruffled fan palm (Licuala grandis) (Selvaraj et al., 2017).

RSW sucks the plant sap and it leads to phytotoxic effect on coconut. RSW secretes white waxy material and a profuse amount of honeydew, which favours the sooty moldy fungal growth and negatively influences the plant's photosynthesis, thus indirectly affecting the quality of nuts. Elango and Nelson (2020) recorded twenty host plants of RSW in Tamil Nadu, among which coconut and banana plants supported all the life stages of RSW. The present study was aimed to was aimed to investigate the biology and morphometric analysis of RSW, A. rugioperculatus on coconut.

\section{MATERIALS AND METHODS}

\section{Mass culturing of RSW}

Initially, RSW-infested coconut (Cocos nucifera L) leaflets were collected at the Tamil Nadu Agricultural University (TNAU) orchard $\left(11.0123^{\circ} \mathrm{N}, 76.9355^{\circ} \mathrm{E}\right)$, Coimbatore, Tamil Nadu, India, and released onto mud potted (41 cm diameter) plants of coconut which were kept in a separate mini net house $(270 \times 150 \times 210 \mathrm{~cm}$ with a nylon net mesh sized of 120 micron). RSW rearings were maintained in the Insectary, Department of Agricultural Entomology at $31 \pm 2{ }^{\circ} \mathrm{C}, 60-75 \% \mathrm{RH}$ under a natural light condition.

\section{Biology of $A$. rugioperculatus on different host plants}

A pair of adult whiteflies (male and female) was put into a clip cage ( 2 cages per plant) with dimensions of $3 \mathrm{~cm}$ diameter $\times 3 \mathrm{~cm}$ height and placed on a potted coconut plant which was kept for $24 \mathrm{~h}$ inside different mini net houses. The following day, two egg spirals were observed on the coconut plant. Totally thirty eggs (15 eggs/egg spiral) were considered to study the biology of A. rugioperculatus on each host plant. Each egg was taken as a replication. White waxy fluff covering the egg spiral was gently blown off using a straw to facilitate the visualization of eggs, and excess eggs were removed using a very small insect pin. After hatching, the first nymphs moved a millimetre distance from the egg case and permanently settled on the leaf surface. After settling, nymphs reached the phloem of the host plants and remained sedentary until they reached the adult stage. The developmental time for each life stage of RSW was recorded (Boughton et al., 2015)

\section{Morphometry of $\boldsymbol{A}$. rugioperculatus}

The whitefly exposure techniques described above were used; clip cages with whiteflies were placed on each potted coconut plant's leaf portion to oviposit for $24 \mathrm{~h}$. Freshly laid egg spiral was observed for life stag- es development. Then immature stages of RSW were excised daily and examined under 40x binocular stereo microscope. Measurements on eggs, nymphal stages, pupae and adults were made using Leica image analyser (Leica M205C) using LAS X software.

\section{RESULTS AND DISCUSSION}

\section{Biology and morphometry of $A$. rugioperculatus on coconut}

RSW has egg, nymphal, pupal and adult stage (Plate 1). Total developmental time of $A$. rugioperculatus was $56.23 \pm 2.20$ days. Developmental time and morphometric measurements were included in Table 1 and 2.

\section{Egg}

Adults were laid smooth, transparent, whitish yellow and elliptical shape eggs in spiral manner on undersurface of the leaves. Egg spiral was covered with white flocculant material and each egg spiral contained 29 eggs. Egg period of RSW was $8.47 \pm 0.26$ days. Eggs were $0.31 \pm 0.01 \mathrm{~mm}$ in length and $0.11 \pm 0.02 \mathrm{~mm}$ in width.

\section{First nymphal stage}

Nymphs were elliptical in shape and yellowish in colour. It has functional legs, moved short distance to find a suitable site for feeding and lack their eggs. The first nymphal stage was called a crawler. The first nymphal period of RSW was $5.80 \pm 0.19$ days. First nymphal were $0.34 \pm 0.01 \mathrm{~mm}$ in length and $0.18 \pm 0.01 \mathrm{~mm}$ width.

\section{Second nymphal stage}

Nymphs were sedentary and oval, transparent and yellowish in colour and has the initiation of white waxy covering on dorsal outline of the body. Second nymphs were $0.53 \pm 0.01 \mathrm{~mm}$ in length and $0.79 \pm 0.02 \mathrm{~mm}$ in width. The second nymphal period was $5.03 \pm 0.34$

Table 1. Biology of $A$. rugioperculatus on coconut.

\begin{tabular}{ll}
\hline Developmental stages & $\begin{array}{l}\text { Duration (days) } \\
\text { (Mean } \pm \text { SE) }\end{array}$ \\
\hline Egg & $8.47 \pm 0.26$ \\
First nymphal stage & $5.80 \pm 0.19$ \\
Second nymphal stage & $5.03 \pm 0.34$ \\
Third nmphal stage & $6.63 \pm 0.20$ \\
Fourth or Pseudopupal stage & $10.30 \pm 0.29$ \\
Egg - Adult emergence & $36.23 \pm 1.51$ \\
Adult Longevity & $20.00 \pm 1.00$ \\
Total development period & $56.23 \pm 2.20$ \\
\hline
\end{tabular}


Saranya M. et al. / J. Appl. \& Nat. Sci. 13 (SI), 100 - 104 (2021)

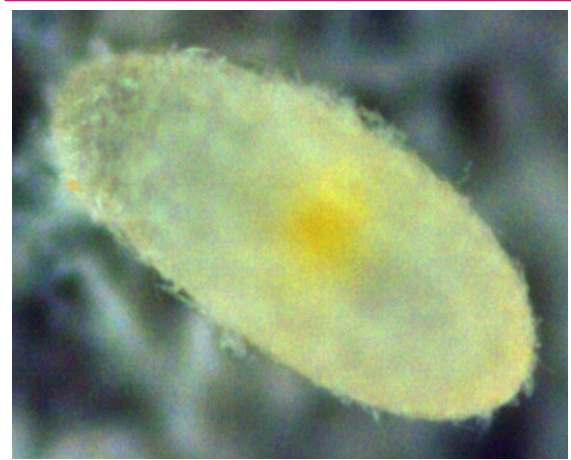

Egg

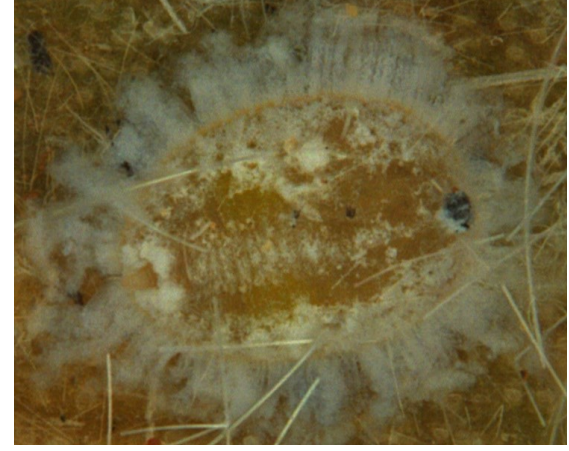

Third nymphal stage

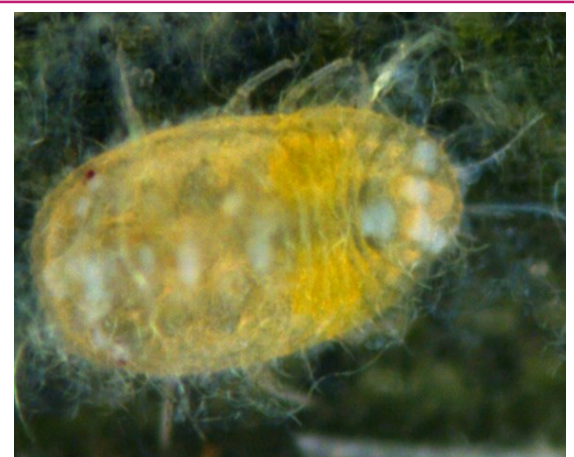

First nymphal stage (crawler)

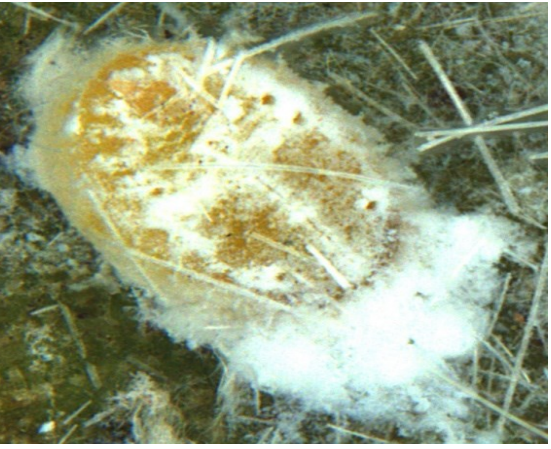

Pupal stage

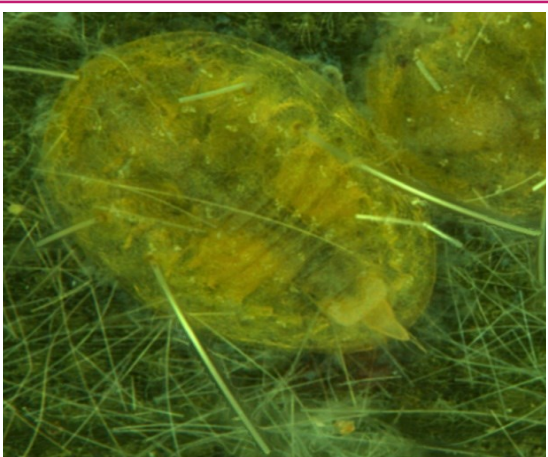

Second nymphal stage

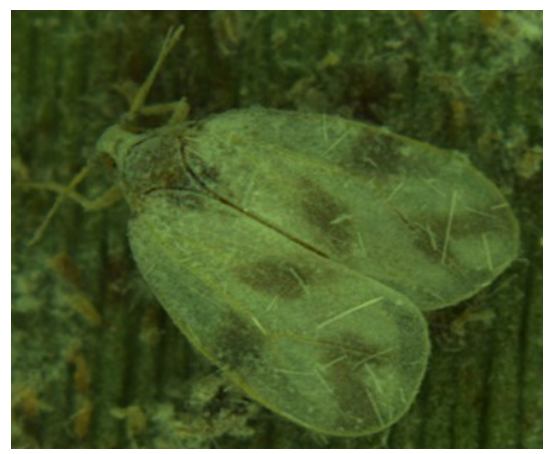

Adult

Plate 1. Life stages of rugose spiraling whitefly.

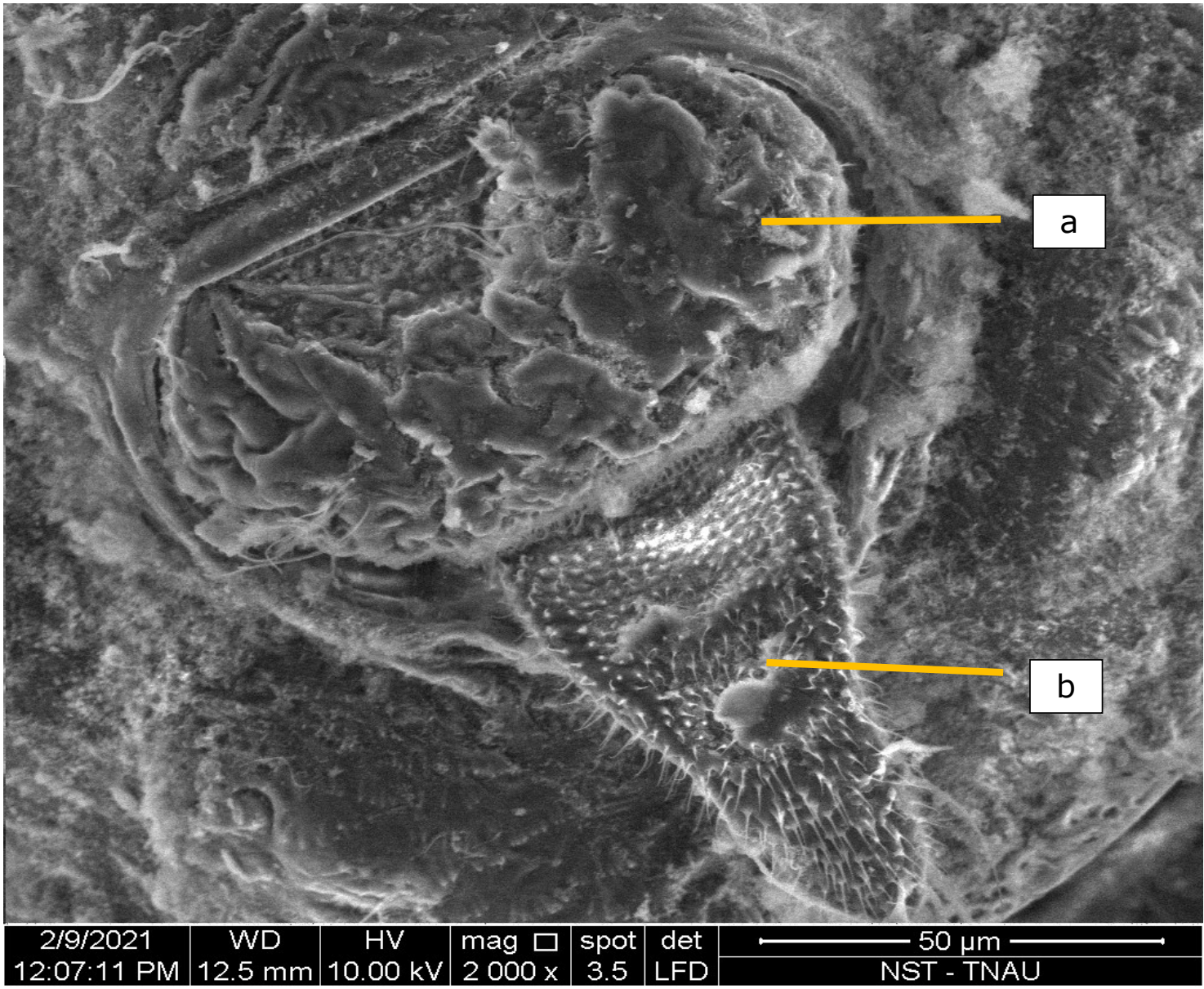

Plate 2. Key characters of RSW by SEM micrograph: Operculum of RSW-corrugated or wrinkled or rugoseness, because of this character common name is called rugose spiralling whitefly; Lingula- Triangular in shape. 
Table 2. Morphometric analysis of developmental stages RSW on coconut.

\begin{tabular}{lll}
\hline \multirow{2}{*}{ Developmental stages } & \multicolumn{2}{c}{ Morphometry } \\
\cline { 2 - 3 } & Length $(\mathrm{mm})$ & Width $(\mathrm{mm})$ \\
\hline Egg & $0.31 \pm 0.01$ & $0.11 \pm 0.02$ \\
First nymphal stage & $0.34 \pm 0.01$ & $0.18 \pm 0.01$ \\
Second nymphal stage & $0.53 \pm 0.01$ & $0.79 \pm 0.02$ \\
Third nmphal stage & $0.94 \pm 0.01$ & $0.82 \pm 0.01$ \\
$\begin{array}{l}\text { Fourth or Pseudopupal } \\
\text { stage }\end{array}$ & $1.23 \pm 0.01$ & $1.00 \pm 0.01$ \\
\hline
\end{tabular}

days.

\section{Third nymphal stage}

Nymphs were sedentary and yellowish in colour. Enormous number of white waxy rods covered on dorsal margin of the body. Waxy rods produces from wax gland which is present in the abdominal segments. Third nymphal period was $6.63 \pm 0.20$ days and their body measurements were $0.94 \pm 0.01 \mathrm{~mm}$ in length and $0.82 \pm 0.01 \mathrm{~mm}$ in width

\section{Fourth nymphal or pseudopupal stage}

Nymphs were sedentary and yellowish in colour. Body densely covered with white waxy material. Operculum corrugated and lingula was triangular in shape (Plate 2). Pupal period was $10.30 \pm 0.29$ days. Pupal was $1.23 \pm 0.01 \mathrm{~mm}$ in length and $1.00 \pm 0.01 \mathrm{~mm}$ in width

\section{Adults}

Adult survived for $20.00 \pm 1.00$ days. Adult emerged from pupa through $\mathrm{T}$ shape exit hole. Pair of three brown spots on wings. Males had pincer like structure at their abdomen

Studying the biology of RSW provide knowledge to reduce the spread of this whitefly in the future (Taravati et al. 2016). The present study results reported that developmental period of RSW from egg to adult was $36.23 \pm 1.51$ days. Similarly, Elango et al. (2019) reported the developmental period needed for RSW was 37.00 days on coconut. The developmental time of RSW on the white bird paradise plant was 31.1 days, as reported previously by Boughton et al. (2015). Shorter developmental time of RSW in coconut (37.6 days) than in banana (48.7 days) or Indian shot plants (42.9 days) under caged conditions. The developmental time of RSW greatly depended on host plant characters and environmental factors. In host plant characteristics includes physical (waxy coating, fibrous lamina, hairiness of leaves) and chemical characters influenced the developmental duration of the RSW. Host plant which favours the development and shortens the developmental time of RSW may be avoided as inter- cropped with coconut (Pradhan et al., 2020). Encarsia guadeloupae is a nymphal parasitoid, can be considered as a potential candidate for the management of RSW.

\section{Conclusion}

It was concluded that the developmental time of RSW from egg to adult was $36.23 \pm 1.51$ days and adults were survived up to $20.00 \pm 1.00$ days. Understanding the bionomics and reproduction potential of RSW would help assess the host-parasitoid interaction for biocontrol management of RSW.

\section{Conflict of interest}

The authors declare that they have no conflict of interest.

\section{REFERENCES}

1. Boughton, A.J., Mendez, M.A., Francis, A.W., Smith, T.R., Osborne, L.S. \& Mannion, C.M. (2015). Host stage suitability and impact of Encarsia noyesi (Hymenoptera: Aphelinidae) on the invasive rugose spiraling whitefly, Aleurodicus rugioperculatus (Hemiptera: Aleyrodidae), in Florida. Biological Control, 88(1), 61-67. DOI:10.1016/j.biocon trol.2015.04.016.

2. Elango, K. \& Nelson, S.J. (2020). Effect of host plants on the behaviour of rugose spiralling whitefly (Aleurodicus rugioperculatus) and their natural enemies. Research Journal of Agricultural Sciences, 11(1), 120-123. DOI: 5757-2812-024.

3. Elango, K., Nelson, S.J., Sridharan, S., Paranidharan, V. \& Balakrishnan, S. (2019). Biology, distribution and host range of new invasive pest of India coconut rugose spiralling whitefly (Aleurodicus rugioperculatus) Martin in Tamil Nadu and the status of its natural enemies. International Journal of Agriculturure Sciences, 11(9), 8423-8426. ISSN. 2019:0975-3710.

4. Francis, A.W., Stocks, I.C., Smith, T.R., Boughton, A.J., Mannion, C.M. \& Osborne, L.S. (2016). Host plants and natural enemies of rugose spiraling whitefly (Hemiptera: Aleyrodidae) in Florida. Florida Entomologist, 99(1), 150153. DOI: 10.1653/024.099.0134.

5. Martin, J.H. (2004).Whiteflies of Belize (Hemiptera: Aleyrodidae). Part 1-introduction and account of the subfamily Aleurodicinae Quaintance \& Baker. Moscas blancas de Belice (Hemiptera: Aleyrodidae). Parte 1introducción y descripción de la subfamilia Aleurodicinae Quaintance \& Baker. Zootaxa, 681, 1-119. DOI: 681.1.1/0.

6. Pradhan, S.K., Anshylesha, K. \& Sumalatha, B.V. (2020). Comparative biology of invasive rugose spiralling whitefly Aleurodicus rugioperculatus Martin on three host plants. Indian Journal of Entomology, 82(3), 498-503. DOI: 10.5958/0974-8172.2020.00125.X.

7. Selvaraj, K., Gupta, A., Venkatesan, T., Jalali, S.K., Ballal, C.R. \& Sundararaj, R. (2017). First record of invasive rugose spiraling whitefly Aleurodicus rugioperculatus Martin (Hemiptera: Aleyrodidae) along with parasitoids in Karna- 
taka. Journal of Biological Control, 31(2), 74-78. DOI: 10.18311/jbc/2017/16015.

8. Stocks, I.C. \& Hodges, G. (2012). The rugose spiraling whitefly, Aleurodicus rugioperculatus Martin, a new exotic whitefly in South Florida (Hemiptera: Aleyrodidae). Gainesville (FL): Florida Department of Agriculture and Consumer Services, Division of Plant Industry Aleurodi- cus rugioperculatus, pest-alert. DACS-P-01745 pdf (Accessed 7 March, 2017).

9. Taravati, S., Mannion, C., McKenzie, C. \& Osborne, L. (2016). Oviposition preference of rugose spiraling whitefly (Hemiptera: Aleyrodidae) on five host plant species. Florida Entomologist, 110(4), 611-616. DOI:10.1 653/ 024.10 1.0423 . 